\title{
RESULTS OF TOTAL LUMBAR INTERVERTEBRAL DISK REPLACEMENT WITH M6-L: A MULTICENTER STUDY
}

\author{
RESULTADOS DA SUBSTITUIÇÃO TOTAL DE DISCO INTERVERTEBRAL LOMBAR \\ COM M6-L: UM ESTUDO MULTICÊNTRICO
}

\section{RESULTADOS DE LA SUSTITUCIÓN TOTAL DE DISCO INTERVERTEBRAL LUMBAR CON M6-L: UN ESTUDIO MULTICÉNTRICO} \author{
Valeriy Vladimirovich ShepeleV ${ }^{4}$ \\ 1. Railway Clinical Hospital, Irkutsk, Russia. \\ 2. Irkutsk State Medical University, Irkutsk, Russia. \\ 3. Krasnoyarsk Regional Clinical Hospital, Krasnoyarsk, Russia. \\ 4. 1477 Naval Clinical Hospital of the Russian Defense Ministry, Vladivostok, Russia.
}

Vadim Anatol'evich Byvaltsev ${ }^{1,2}$, Andrel Andreevich Kalinin ${ }^{1,2}$, Ivan Andreevich Stepanov ${ }^{1,2}$, Yuri Yakovlevich Pestryakov ${ }^{3}$,

\begin{abstract}
Objective: In this paper we report the clinical and radiological results of lumbar intervertebral disk (IVD) replacement with M6-L for the treatment of patients with IVD degeneration. Methods: One hundred and fifty-six patients with IVD degeneration were operated with the one level implantation of an M6-L prosthesis at three neurosurgical departments, in Irkutsk, Krasnoyarsk and Vladivostok. We assessed pain intensity (VAS), the Oswestry disability index (ODI) and outcomes by the Macnab scale up to 36 months after surgery. Instrumental data were used to assess range of motion in the operated segment and heterotopic ossification by the McAfee-Suchomel classification. Results: The average VAS before surgery was $6.9 \pm 1.6 \mathrm{~cm}$. After surgery, this value reduced significantly, to an average of $1.3 \pm 1.2 \mathrm{~cm}(\mathrm{p}<0.001)$. The average ODI before surgery was $40.2 \pm 6.9 \%$, and after IVD arthroplasty, this indictor improved to $12.3 \pm 6.1 \%(p<0.001)$. Range of motion in the operated segment at baseline averaged $36.8 \pm 2.6^{\circ}$, and within 36 months after the operation, this had increased to $41.2 \pm$ $2.9^{\circ}$. During the entire follow-up period, signs of severe $(13.4 \%, n=21)$ or moderate $(10.2 \%, n=16)$ heterotopic ossification were observed. Conclusions: The use of M6-L prosthesis can significantly reduce the level of pain, improve quality of life and maintain the physiological range of motion in the operated spinal segment in patients with degenerative lesions IVD at a low level of adverse outcomes. [249 Words].
\end{abstract}

Keywords: Spine; Intervertebral disc; Arthroplasty; Lumbar vertebrae; Prosthesis design.

\section{RESUMO}

Objetivo: Neste artigo, relatamos os resultados clínicos e radiológicos da substituição de disco intervertebral lombar (IVD) com M6-L para tratamento de pacientes com degeneração de IVD. Métodos: Cento e cinquenta e seis pacientes com degeneração de IVD foram operados com a implantação de prótese M6-L em um nível, em três departamentos neurocirúrgicos de Irkutsk, Krasnoyarsk e Vladivostok. Avaliamos a intensidade da dor (EVA), o Índice de Incapacidade de Oswestry (ODI) e os resultados pela escala de Macnab até 36 meses após a cirurgia. Os dados de instrumentação foram utilizados para avaliar a amplitude de movimento no segmento operado e a ossificação heterotópica pela classificação McAfee-Suchomel. Resultados: O valor médio da EVA para dor antes da cirurgia foi de 6,9 \pm 1,6 cm. Após a cirurgia, esse valor teve redução significativa, em média de 1,3 $\pm 1,2 \mathrm{~cm}(p<0,001)$. O ODI médio antes da cirurgia foi de 40,2 $\pm 6,9 \%$, e depois da artroplastia do IVD esse índice melhorou para 12,3 $\pm 6,1 \%$ ( $p<0,001)$. A amplitude de movimento do segmento operado no início do estudo foi em média 36,8 $\pm 2,6^{\circ}$ e 36 meses após a cirurgia, aumentou para 41,2 $\pm 2,9^{\circ}$. Durante todo o acompanhamento, foram observados sinais de ossificação heterotópica grave $(13,4 \%, n=21)$ ou moderada $(10,2 \%, n=16)$. Conclusões: O uso da prótese M6-L pode reduzir significativamente o nível de dor, melhorar a qualidade de vida e manter a amplitude de movimento fisiológico no segmento espinal operado em pacientes com lesões degenerativas do IVD com baixo nível de desfechos adversos.

Descritores: Coluna vertebral; Disco intervertebral; Artroplastia; Vértebras lombares; Desenho de prótese.

\section{RESUMEN}

Objetivo: En este trabajo, relatamos los resultados clínicos y radiológicos de la sustitución de disco intervertebral lumbar (IVD) con M6-L para tratamiento de pacientes con degeneración de ND. Métodos: Ciento cincuenta y seis pacientes con degeneración de IVD fueron operados con la implantación de prótesis M6-Len un nivel, en tres departamentos de neurocirugía de Irkutsk, Krasnoyarsky Vladivostok. Se evaluó la intensidad del dolor (EVA), el Índice de Discapacidad de Oswestry $(O D I)$ y los resultados por escala de Macnab hasta 36 meses después de la cirugía. Los datos de instrumentación se utilizaron para evaluar el rango de movimiento en el segmento operado y la osificación heterotópica mediante la clasificación de McAfee-Suchomel. Resultados: El valor promedio de la EVA para el dolor antes de la cirugía fue de 6,9 $\pm 1,6 \mathrm{~cm}$. Después de la cirugía, ese valor tuvo una reducción significativa, en promedio de 1,3 $\pm 1,2 \mathrm{~cm}$ ( $p<0,001)$. El ODI promedio antes de la cirugía fue de 40,2 $\pm 6,9 \%$ y después de la artroplastia del IVD ese índice mejoró para $12,3 \pm 6,1 \%(p<0,001)$. El rango de movimiento del segmento operado al inicio del estudio fue en promedio 36,8 $\pm 2,6^{\circ}$ y 36 meses después de la cirugía, aumentó a 41,2 $\pm 2,9^{\circ}$. Durante toda el seguimiento se observaron signos de osificación heterotópica grave $(13,4 \%, n=21)$ o moderada $(10,2 \%, n=16)$. Conclusiones: El uso de la prótesis M6-L puede reducir significativamente el nivel de dolor, mejorar la calidad de vida y mantener el rango de movimiento fisiológico en el segmento espinal operado en pacientes con lesiones degenerativas de IVD con bajo nivel de resultados adversos.

Descriptores: Columna vertebral; Disco intervertebral; Artroplastia; Vértebras lumbares; Diseño de prótesis. 


\section{INTRODUCTION}

Low back pain is one of the most pressing health problems in industrialized countries. ${ }^{1}$ Vertebrogenic pain is often associated with patients with early and persistent disability. ${ }^{2,3}$ Depending on the severity of the clinical symptoms and the degree of degenerative changes in the intervertebral disk (IVD), as shown in the neuroimaging results, a decision is made on whether to perform conservative treatment or surgery. ${ }^{4}$

The main method of surgical treatment of discogenic lesions of the lumbar spine is microdiscectomy. However in some cases, reduces the height of the IVD and recurrent herniation, as well as the formation of abnormal segmental mobility, with the return of compression of the spinal canal content, various methods of instrumental fusion and fixation have been developed. ${ }^{5}$

Rigid stabilization is used to remove or prevent the instability of the affected segment, and involves the formation of a bone block and complete restriction of his mobility. The main disadvantage of fusion is the progression of pathological changes in the adjacent IVD, due to poor load distribution. ${ }^{6}$

The development of artificial IVD helps prevent degeneration of adjacent segments by restoring the natural biomechanics and physiological range of motion in the operated segments. ${ }^{7}$

Studies on the use of artificial discs have demonstrated their high efficacy against clinical and instrumental outcomes in patients with degenerative IVD compared to spinal fusion surgery. ${ }^{7}$ Various structures have emerged in the form of functional IVD prostheses aimed at optimizing postoperative outcomes, but the results of their application are ambiguous. . $^{8-10}$

The purpose of this study is conduct a multicenter analysis of the application of IVD M6 arthroplasty prosthesis for the lumbar spine.

\section{METHODS}

This multicenter study included 156 patients who underwent total arthroplasty IVD lumbar spine prosthesis M6 at the center of Neurosurgery of MSH Road Clinical Hospital, at the station Irkutsk-Passenger JSC "Russian Railways", the neurosurgical department of the Krasnoyarsk regional clinical hospital, and the neurosurgical department 1477 MilitaryNavy clinical hospital of the Russian Ministry of Defense.

The inclusion and exclusion criteria of the study are presented in Table 1. ${ }^{11-14}$

In the preoperative period, all patients were submitted to comprehensive clinical and instrumental assessment of complaints, medical history, neurological status, radiological (standard spondylography in two projections) and neuroimaging (magnetic resonance imaging at 1.5 T unit Magnetom Siemens Essenza, multislice computed tomography in a Bright Speed Edge tomograph).

We studied the technical characteristics of surgical intervention (operative time, estimated blood loss), especially in the post-operative period (activation time, duration of hospital treatment, the presence of complications).

Table 1. Inclusion and exclusion criteria of the study

\begin{tabular}{c|c}
\hline Inclusion criteria & Exclusion criteria \\
\hline $\begin{array}{c}\text { Degenerative changes in the } \\
\text { IVD without the spinal canal } \\
\text { stenosis (Pfirmann grade I-II })^{11}\end{array}$ & Osteoporosis \\
\hline $\begin{array}{c}\text { Minimal degenerative changes in } \\
\text { the facet joints (Fujiwara grade I-II) }\end{array}$ & Segmental instability \\
\hline $\begin{array}{c}\text { Persistent pain resistant } \\
\text { to conservative therapy } \\
\text { (within 4-6 weeks) }\end{array}$ & $\begin{array}{c}\text { Spondylarthrosis with } \\
\text { compensatory changes in the facet } \\
\text { joints with limited range of motion }\end{array}$ \\
\hline $\begin{array}{c}\text { Safety height interbody gap (more } \\
\text { than 50\% of the overlying) }\end{array}$ & Congenital spinal stenosis \\
\hline $\begin{array}{c}\text { Preservation of physiological } \\
\text { range of motion in the segment } \\
\text { (linear translation of no more } \\
\text { than } 4 \text { mm., sagittal angulation } \\
\left.\text { of not more than } 10^{\circ}\right)^{14}\end{array}$ & Earlier surgery on the segment \\
\hline
\end{tabular}

For the dynamic assessment in the 36 months after surgery, clinical parameters were used (Oswestry disability index (ODI), pain intensity on the visual analog pain scale (VAS), subjective satisfaction with the results of the surgical treatment (according to the Macnab scale) and instrumental data (range of motion in the operated segment, and degree of heterotopic ossification by the McAfee-Suchomel classification).

The study was approved by the ethics committee of the Irkutsk State Medical University (protocol \# 541/18 of February 19, 2016).

Statistical analysis was performed using Microsoft Excel software version 2010. Descriptive statistics are presented as $M \pm S D$, where $M$ is the mean value, and SD is the standard deviation. Categorical variables are presented in percentages. The statistical accuracy of the indicators before the operation, and in the early postoperative period and trimmed ( $p$-value), were determined using a paired t-test. The lower limit of significance was $p<0.05$.

\section{RESULTS}

The average height of the patients was $170.2 \pm 9.6 \mathrm{~cm}$, and the average weight was $68.3 \pm 10.6 \mathrm{~kg}$. In 103 cases (66\%), the surgical intervention was performed on level L5-S1, in 43 (27.5\%) patients it was performed on L4-5 and in 10 patients (6.5\%), at IVD prosthesis L3-4. The mean surgery time was $104 \pm 14.07$ minutes, the average blood loss was $157.7 \pm 36.7 \mathrm{ml}$, and the mean hospitalization time was $8.3 \pm 1.4$ days

When analyzing the quality of life of patients by the ODI, there were significant positive dynamics for functional state after surgery, compared with the preoperative value: from an average of $40.2 \pm$ $6.9 \%$ before surgery, to $12.5 \pm 7.3 \%$ at six months after surgery (t- test, $\mathrm{p}<0.001$ ). In the follow-up, statistically significant changes in quality of life were recorded, and over the 36 months, these changes amounted to $12.3 \pm 6.1 \%$ (Figure 1). According to published data, the 10-point decrease in quality of life on the Oswestry scale is associated with achievement of the minimum clinical difference (MCD) in the patient's condition before and after treatment. ${ }^{13}$ In the present study, all patients achieved MCD.

After the operation, there was a significant decrease in pain intensity in all patients $(n=156)$. Pain assessment using the VAS identified a positive trend in the form of a significant reduction in its intensity after surgery, from an average of $6.9 \pm 1.6 \mathrm{~cm}$ before surgery to an average of $1.2 \pm 1.9 \mathrm{~cm}$ six months after surgery (t-test, $p<0.001$ ), while maintaining the minimum of its values throughout the study and at 36 months after surgery, the severity of pain according to VAS was $1.3 \pm 1.2 \mathrm{~cm}$ (Figure 2). It is believed that the decrease in the intensity of back pain at $1.8-1.9 \mathrm{~cm}$ VAS is equivalent to achieving MCD. $8,10,14$ According to our data, with the dynamic assessment of the severity of pain in the back pain MCD reached all the studied patients.

In the analysis of patient satisfaction with the results of surgical intervention on the Macnab subjective scale, the dynamics revealed mostly good and excellent outcomes (90\%) (Figure 3). This confirms the functional viability of the operated spine and social adaptation of the operated patients.

In the study, no adverse effects associated with the immediate installation of the stabilizing structures were found in any of the

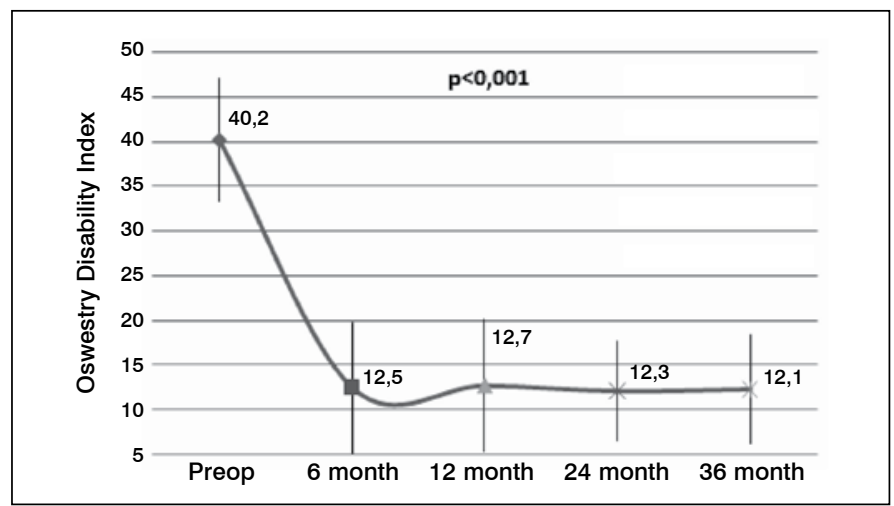

Figura 1. Mean Oswestry Disability Index (\%). 
groups. In the analysis, two (1.3\%) cases of abdominal hematoma formation were found, and one case of retrograde ejaculation $(0.6 \%)$. In addition, three patients $(1.9 \%)$ had iliac vessel injury in intraoperative mobilization process. In these cases, microsurgical vascular suture was performed, to prevent blood loss and adverse outcomes in the patient.

All patients underwent functional spondylography of the lumbar spine in the study period without this words.

Range of motion in the operated spinal segment remained within the physiological limits: range of motion in the operated segment before surgery averaged $36.8 \pm 2.6^{0}$; after six months of follow-up the range of motion was $41.1 \pm 2.8^{\circ}$ and 36 months after the arthroplasty, $41.2 \pm 2.9^{\circ}$ (Figure 4). Signs of instability were observed in the structural elements.

When evaluating the results of the dynamic magnetic resonance imaging of the lumbar spine performed at a mean of 36 months after

surgery, we have been identified signs of degenerative process progression in the adjacent segment.

According to our data, over the entire observation period, we found initial $(13.4 \%, n=21)$ or moderate $(10.2 \%, n=16)$ signs of heterotopic ossification (I-II degree in the McAfee-Suchomel classification). ${ }^{15}$

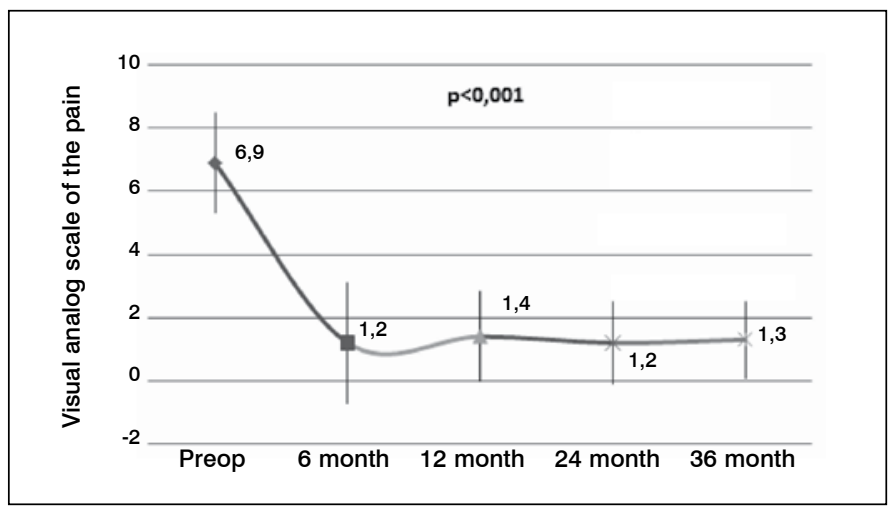

Figura 2. Mean low back pain on the VAS (cm).

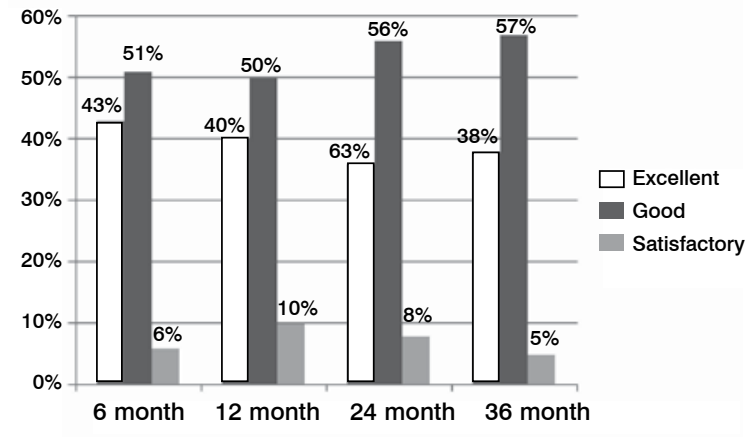

Figura 3. Subjective patient satisfaction surgery on the Macnab scale.

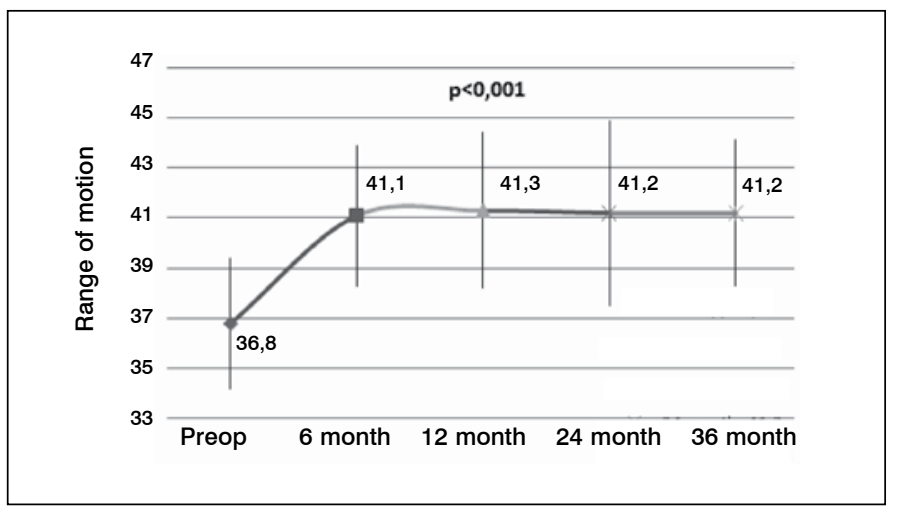

Figura 4. Mean range of motion $\left(^{\circ}\right)$

\section{DISCUSSION}

A large number of studies of the results of stabilizing and decompressive surgical interventions indicate the development of non-physiological biomechanical distribution of load to adjacent segments. ${ }^{16}$ These factors contributed to the development of new technological solutions in spinal surgery, which helped regain the motion in the affected segment, reduce the load on the adjacent levels, and prevent the progression of the degenerative process. This innovative trend became a technique of total arthroplasty of the IVD, and is now a popular method of treating patients.

A new generation of artificial limbs with a hydrogel or polyurethane core has been developed for total arthroplasty of the IVD. Their main tasks are to restore IVD function by absorbing the impact of fluid in the intervertebral space, and proper distribution of the emerging axial load. ${ }^{17}$ Among these physiological prostheses, the most widely used are the Charite (Link Spine Group), ProDisc (Spine Solutions), AcroFlex (DePuy AcroMed), and M6 (Spinal Kinetics)..$^{18}$

Clinical efficiency of IVD prostheses in the specialized literature is interpreted ambiguously. Thus, the study by Sasso et al., ${ }^{6}$ using the MTD Flexi Core (Stryker Spine) prosthesis in the early postoperative period, showed decreased severity of pain according to VAS from $8.6 \mathrm{~cm}$ to $3.6 \mathrm{~cm}$, and the quality of life values ODI increased from 62 to 36 points. In another study which applied the Maverick prosthesis (Spine-Health), the severity of pain according to VAS decreased from $8.4 \mathrm{~cm}$ to $2.8 \mathrm{~cm}$, and quality of life on the ODI increased from 69 to 35 points. ${ }^{19}$ In the study of Abakirov et al., ${ }^{20}$ using the IVD M6 prosthesis, the following clinical results were obtained: reduction in severity of pain according to VAS from $5.5 \mathrm{~cm}$ to $3.4 \mathrm{~cm}$, and in quality of life on the ODI from increased 56 to 27 points.

According to Le Huec et al. ${ }^{21}$ from $73 \%$ to $77 \%$ of patients achieved by MCD with a one-tier with a one-tier and two-tier arthroplasty prosthesis ProDisc IVD, respectively. Using the prosthesis IVD Charite MCD increased $47 \%$ to $51 \%$, the Maverick IVD prosthesis $47-63 \%$, ${ }^{22}$ the prosthesis M6-Lumbar 51-66\% patients. ${ }^{23}$ According to the literature, the achievement of MCD of patients by VAS varies over a wide range from $41 \%$ to $79 \%,{ }^{21} 58-75 \%,{ }^{22} 46 \%-64 \%{ }^{23}$ and from 53 to $72 \%$. ${ }^{24}$ According to our data, all patients achieved MCD according to the analysis of quality of life questionnaires Oswestry and VAS.

Thus, the results of the application of techniques of total prosthesis IVD in the lumbosacral spine is largely dependent on the type of prosthesis and preferences of the neurosurgeon doctor. Despite the differences in the results obtained for the use of structurally distinct IVD prosthesis, studies confirm the clinical effectiveness of using total prosthetics IVD.

The most important indicator when performing total arthroplasty of the IVD is the range of motion of the operated segment. We observed an increase in the average range of motion of the operated segment of 4.40 , which is consistent with the results of a number of foreign researchers. In the study of Le Huec et al. ${ }^{21} 35$ patients after total arthroplasty of the Maverick IVD prosthesis showed an increase range of motion on, who had undergone total arthroplasty with the Maverick prosthesis IVD, showed an increase of 5.10 (for LIV-LV level) and 4.90 (for LV-S1 level). Berg et al. ${ }^{22}$ using the prosthesis ProDisc noted an increase in range of motion in the operated segment, an average of 8.40. In the study of Guyer et al. ${ }^{23}$ using the M6-L prosthesis, range of motion of the operated segment increased by an average of $60^{\circ}$.

According to the literature, complications after total arthroplasty IVD range from $1 \%$ to $40 \%$. In our study, the rate was $3.2 \%$. This difference in percentage can be explained by different methods and approaches to the implementation of the IVD prosthesis in various clinics around the world, as well as the experience of the surgeon. ${ }^{24}$ One of the most dangerous and tragic complications in surgery is damage to major vessels. In the literature, damage to the iliac vessels at the adrectal retroperitoneal access to the spine occurs in 1.9-2.9\% of cases. ${ }^{21}$ In our study, damage to the iliac vessels was observed in $3(1.9 \%)$ patients. Retrograde ejaculation occurs according to various authors in $0.1-4.1 \%$ of cases. Based on our data, this kind of complication was observed in one $(0.64 \%)$ patients.

Infectious complications in the surgical wound are not uncommon, due to the large spread of pathogenic microorganisms resistant to the action of different antimicrobial agents, reduced immune 
defenses of the patient, and the presence of somatic diseases of different spectrums (diabetes, chronic heart failure, chronic kidney disease. According to various authors, complications of this kind occur in $0.9-6.3 \%$ of cases. ${ }^{25}$ During our study, there were no surgical wound infections.

The phenomena of spontaneous heterotopic ossification with artificial IVD implantation is a pressing problem in spinal surgery. Heterotopic ossification refers to disorders that are characterized by the formation of bone tissue, which normally do not have osteogenic properties. Nevertheless, it bears all the signs of structural and functional disability. ${ }^{8}$ The causes and mechanism of formation of foci of heterotopic ossification are not clear. Metabolic disorders, trauma, neurogenic and genetic factors played a major role in heterotopic ossification formation. ${ }^{10}$

According to the specialized literature, bone heterotopia is a frequent complication of prosthetic IVD. In a study by Kim et al. ${ }^{15}$, after 36 months of follow-up, degree I-II heterotopic ossification was identified in 56\% of cases, and degree III ossification in 3\% of cases. In Barbagallo et al. ${ }^{26}$ after a two-year observation period, signs of bone heterotopias were found in $42.2 \%$ of cases. Jin et al. ${ }^{27}$ observed that within 45 months, signs of heterotopic ossification were apparent in $30.5 \%$ of cases, while degree I ossification occurred in $9.8 \%$ of cases, degree II in $14.6 \%$, and degree III in $6.1 \%$ of cases. According to our data, we have noted $13,4 \%(n=21)$ patients with grade $1-2$ and 10,2 $\%(n=16)$ with grade 3 heterotopic ossification.

In this clinical series for total arthroplasty IVD lumbar spine, an M6-L prosthesis was used. This innovative system includes an artificial nucleus pulposus, providing mobility with controlled amplitude and six degrees of freedom, and an artificial fibrous ring of fibrous material, to counteract axial compression. Physiological mobility is designed to preserve spinal segment mobility and prevent further degeneration in the adjacent IVD. ${ }^{23}$

Given the novelty and the high cost (instruments, implants) described, techniques accumulated in the present time in spinal surgery, the amount of information relating to the clinical and radiological efficacy of artificial intervertebral disc prosthesis is insufficient. It requires the continuation of multicenter studies involving a larger number of respondents, as well as a detailed study of long-term clinical and instrumental findings, to clarify the indications for the use of dynamic fixation.

\section{CONCLUSION}

The use of artificial intervertebral disc M6-L can significantly reduce the level of pain, improve quality of life, and maintain the physiological range of motion in the operated spinal motion segment in patients with degenerative lesions of the IVD, with a low level of adverse outcomes.

All authors declare no potential conflict of interest related to this article.

CONTRIBUTION OF THE AUTHORS: Each author made significant individual contributions to this manuscript. VAB and AAK were the main contributors in the drafting of the manuscript. AAK and IAS performed the surgical procedures and patient follow-up, and gathered clinical data. YYP evaluated the data from the statistical analysis. VVS performed the literature search and review of the manuscript, and contributed to the intellectual concept of the study.

\section{REFERENCES}

1. Byvaltsev VA, Stepanov IA, Kalinin AA et al. Diffusion weighted magnetic resonance tomography in the diagnosis of intervertebral disk degeneration. Biomedical Engineering. 2016. Vol. 4. p. 253-256.

2. Blondel B, Tropiano P, Gaudart J, Marnay T. Clinical results of total lumbar disc replacement regarding various aetiologies of the disc degeneration: a study with a 2-year minimal follow-up. Spine (Phila Pa 1976). 2011:36(5):E313-9.

3. Belykh E, Krutko AV, Baykov ES, Giers MB, Preul MC, Byvaltsev VA. Preoperative estimation of disc herniation recurrence after microdiscectomy: predictive value of a multivariate model based on radiographic parameters. Spine J. 2017:17(3):390-400.

4. Zigler J, Delamarter R, Spivak JM, Linovitz RJ, Danielson GO 3rd, Haider TT, et al. Results of the prospective, randomized, multicenter Food and Drug Administration investigational device exemption study of the ProDisc-L total disc replacement versus circumferential fusion for the treatment of 1-level degenerative disc disease. Spine (Phila Pa 1976). 2007;32(11):1155-62.

5. José-Antonio SS, Baabor-Aqueveque M, Silva-Morales F. Philosophy and concepts of modern spine surgery. Acta Neurochir Suppl. 2011;108:23-31.

6. Sasso RC. Foulk DM, Hahn M. Prospective, randomized trial of metal-on-metal artificial lumbar disc replacement: initial results for treatment of discogenic pain. Spine (Phila Pa 1976). 2008;33(2):123-31.

7. Guyer RD, McAfee PC, Banco RJ, Bitan FD, Cappuccino A, Geisler FH, et al. Prospective, randomized, multicenter Food and Drug Administration investigational device exemption study of lumbar total disc replacement with the CHARITE artificial disc versus lumbar fusion: five-year follow-up. Spine J. 2009;9(5):374-86

8. Delamarter R, Zigler JE, Balderston RA, Cammisa FP Goldstein JA Spivak JM. Prospective, randomized, multicenter Food and Drug Administration investigational device exemption study of the ProDisc-L total disc replacement compared with circumferential arthrodesis for the treatment of two-level lumbar degenerative disc disease: results at twenty-four months. J Bone Joint Surg Am. 2011:93(8):705-15.

9. Katz J, Melzack R. Measurement of pain. Surg Clin North Am. 1999;79(2):231-52.

10. Zigler JE, Delamarter RB. Five-year results of the prospective, randomized, multicenter, Food and Drug Administration investigational device exemption study of the ProDisc-L total disc replacement versus circumferential arthrodesis for the treatment of single-level degenerative disc disease. J Neurosurg Spine. 2012;17(6):493-501.

11. Pfirrmann CW, Metzdorf A, Zanetti M, Hodler J, Boos N. Magnetic resonance classification of lumbar intervertebral disc degeneration. Spine (Phila Pa 1976). 2001;26(17):1873-8.

12. Fujiwara A, Lim TH, An HS, Tanaka N, Jeon CH, Andersson GB, et al. The effect of disc degeneration and facet joint osteoarthritis on the segmental flexibility of the lumbar spine. Spine (Phila Pa 1976). 2000;25(23):3036-44.

13. Fairbank JC, Couper J, Davies JB, O'Brien JP. The Oswestry low back pain disability questionnaire. Physiotherapy. 1980;66(8):271-3.
14. Siepe CJ, Mayer HM, Wiechert K, Korge A. Clinical results of total lumbar disc replacement with ProDisc II: three-year results for different indications. Spine (Phila Pa 1976) 2006:31(17):1923-32

15. Kim J, Kim Y, Jeong WK, Song SY, Cho OK. Heterotopic ossification developing in surgical incisions of the abdomen: analysis of its incidence and possible factors associated with its development. J Comput Assist Tomogr. 2008:32(6):872-6.

16. Schmidt R, Obertacke U, Nothwang J, Ulrich C, Nowicki J, Reichel H, et al. The impact of implantation technique on frontal and sagittal alignment in total lumbar disc replacement: a comparison of anterior versus oblique implantation. Eur Spine J. 2010:19(9):1534-9.

17. Chung SS, Lee CS, Kang CS, Kim SH. The effect of lumbar total disc replacement on the spinopelvic alignment and range of motion of the lumbar spine. J Spinal Disord Tech. 2006;19(5):307-11.

18. Canbulat N, Sasani M, Ataker Y, Oktenoglu T, Berker N, Ercelen O, et al. A rehabilitation protocol for patients with lumbar degenerative disk disease treated with lumbar total disk replacement. Arch Phys Med Rehabil. 2011;92(4):670-6.

19. Oktenoglu T, Ozer AF, Sasani M, Ataker Y, Gomleksiz C, Celebi I. Posterior transpedicular dynamic stabilization versus total disc replacement in the treatment of lumbar painful degenerative disc disease: a comparison of clinical results. Adv Orthop. 2013;2013:874090

20. Abakirov MD, Kruglov IA, Abdrahmanov RR, Seleznev AS, Mader AE. Ehndoprotezirovanie mezhpozvonkovyh diskov poyasnichnogo otdela pozvonochnika. Hirurgiya Pozvonochnika. 2016; 13(1):59-66

21. Le Huec JC, Mathews H, Basso Y, Aunoble S, Hoste D, Bley B, et al. Clinical results of Maverick lumbar total disc replacement: two-year prospective follow-up. Orthop Clin North Am. 2005;36(3):315-22.

22. Berg S, Tullberg T, Branth B, Olerud C, Tropp H. Total disc replacement compared to lumbar fusion: a randomised controlled trial with 2-year follow-up. Eur Spine J. 2009:18(10):1512-9

23. Guyer RD, Pettine KA, Knight RQ, Dimmig TA, Coric D, McAfee PC, et al. Direct comparison of two lumbar total disc replacement devices: results from a prospective, randomized, multicenter FDA-regulated trial. Spine J. 2010;10(9):S11.

24. Thavaneswaran $P$, Vandepeer M. Lumbar artificial intervertebral disc replacement: a systematic review. ANZ J Surg. 2014;84(3):121-7.

25. Cakir B, Richter M, KäferW, Puhl W, Schmidt R. The impact of total lumbar disc replacement on segmental and total lumbar lordosis. Clin Biomech (Bristol, Avon). 2005:20(4):357-64.

26. Barbagallo GM, Corbino LA, Olindo G, Albanese V. Heterotopic ossification in cervical disc arthroplasty: Is it clinically relevant? Evid Based Spine Care J. 2010;1(1):15-20

27. Jin YJ, Park SB, Kim MJ, Kim KJ, Kim HJ. An analysis of heterotopic ossification in cervical disc arthroplasty: a novel morphologic classification of an ossified mass. Spine $\mathrm{J}$. 2013;13(4):408-20 